\title{
Assessing the Origin of Phosphonic Acid Residues in Organic Vegetable and Fruit Crops: The Biofosf Project Multi-Actor Approach
}

\author{
Alessandra Trinchera ${ }^{1, *(\mathbb{D}}$, Bruno Parisi ${ }^{2}$, Valentina Baratella ${ }^{1}$, Giancarlo Roccuzzo ${ }^{3} \mathbb{C}^{\mathbb{D}}$, \\ Ivano Soave ${ }^{4}$, Carlo Bazzocchi ${ }^{5}$, Daniele Fichera ${ }^{6}$, Mauro Finotti ${ }^{7}$, Francesco Riva ${ }^{8}$, \\ Giacomo Mocciaro ${ }^{9}$, Marco Brigliadori ${ }^{10}$ and Luca Lazzeri ${ }^{2}$ \\ 1 CREA Research Centre for Agriculture and Environment, 00184 Rome, Italy; valentina.baratella@crea.gov.it \\ 2 CREA Research Centre for Cereal and Industrial Crops, 40128 Bologna, Italy; bruno.parisi@crea.gov.it (B.P.); \\ luca.lazzeri@crea.gov.it (L.L.) \\ 3 CREA Research Centre for Olive, Citrus and Tree Fruits, 47121 Forlì, Italy; giancarlo.roccuzzo@crea.gov.it \\ Agrintesa, 48018 Faenza, Italy; i_soave@briospa.com \\ ATBio, 40121 Bologna, Italy; carlo.bazzocchi@gmail.com \\ Federbio, 40121 Bologna, Italy; d.fichera@federbio.it \\ BioTropic, 47167 Duisburg, Germany; mfi@biotropic.com \\ CREA Council for Agricultural Research and Economics, 00198 Rome, Italy; francesco.riva@crea.gov.it \\ PQAI 1 Organic farming Office of the Italian Ministry of Agriculture, Food and Forestry Policies, Mipaaf, \\ 00187 Rome, Italy; g.mocciaro@politicheagricole.it \\ 10 Apofruit Italia, Pievesestina di Cesena, 47522 Forlì-Cesena, Italy; marco.brigliadori@apofruit.it \\ * Correspondence: alessandra.trinchera@crea.gov.it; Tel.: +39-06-7005412-222
}

Received: 28 January 2020; Accepted: 11 March 2020; Published: 19 March 2020

\begin{abstract}
Recently, on the EU market, phosphonic acid residues were detected in many organic goods, although fosetyl-derivates and phosphite salts are not allowed by Reg. EC n. 889/2009. The BIOFOSF project "Solving phosphite issue in organic fruit and horticultural crops" aimed at verifying whether the phosphonic acid contamination could be due to unproper use of fertilizers/plant protection products by organic farmers, or to the plant's ability to self-produce it spontaneously. Applying a participative approach, field case-studies on potato, rocket lettuce, and pears were carried out (organic vs. integrated systems). The ethyl-phosphonic acid and phosphonic acid were determined in soil, tubers, leaves, fruits, tree woody organs, used fertilizers, and plant protection products to correlate them to the applied farming management. Tested crops were not able to self-synthetize phosphonic acid, being its detection due to: (i) external inputs not allowed in organic farming; (ii) fertilizers/plant protection products allowed in organic farming, contaminated by fosetyl or phosphite. In addition, it was found that tree crops can stock the phosphite in their woody organs, then translocate it from branches to leaves and fruits over time. Regression models applied to field data showed that fruit trees decontamination could take more than 5 years, depending on the starting value of phosphonic acid contamination, useful to define the phosphite maximum residue limit in organic fruit crops.
\end{abstract}

Keywords: organic vegetables; phosphonate; fruit tree contamination; participative approach; potato; pear; rocket lettuce

\section{Introduction}

The first systematic studies on the suitability of phosphite as a fertilizer in agriculture date back to the early $1950 \mathrm{~s}$ [1]. For several decades it has been hypothesized that the positive effect deriving from the use of phosphite in fertilization was indirectly linked to the oxidation of phosphite in phosphate 
by soil microorganisms and in plant tissues [2-5]: the molecular and genetic characterization of the biochemical mechanisms of phosphite oxidation in the rhizosphere was indeed reported by Metcalf and Wolfe [6]. Instead, there are no evidences of advantageous effect of phosphite as P source on herbaceous and arboreal plants $[7,8]$. Subsequently, in early 1990s, several research activities were focused on the fungicidal activity of phosphite and its derivatives [5-10]. In fact, number of commercial formulations containing phosphite and organo-phosphonates are universally recognized as highly effective and cheap fungicide.

The physiological responses to phosphite by plants are related to its effect on sugar metabolism, stimulation of the shikimic acid pathway, activation of the ascorbic acid and anthocyanins synthesis [11], or induction of internal hormonal and chemical changes [12]. Its uptake by plants proceeds via leaves and via roots but, while the soil biota promptly oxidizes the phosphite ion into phosphate one [12], in plant tissues the same reduction is not carried out on short time [7-13]. This implies that the application of fosetyl-Al or phosphite salts could determine a potential persistency of the phosphonic acid residues for long term [14]. More recently, some authors defined the potassium phosphite as a plant biostimulant, able to improve crop yield and quality, as well as stimulate environmental stress responses in horticultural crops [15]. Up until now, many progresses were made on the comprehension of phosphite uptake, rapid translocation through xylem-phloem, and following subcellular localization by plants, but still now it is not clear if the phosphite molecule can be synthesized by the crop via phosphate reduction, or if it can derive from external inputs only, such as some plant protection products (i.e. fosetyl-Al or derivates) or fertilizers/biostimulants supplied by foliar spraying [5]. In addition, some animal manure may naturally contain a little amount of phosphite, depending on animal species, diet, biomass storage system, and maturation [16,17].

It should be remarked that fosetyl-Al (i.e., aluminium tris-O-ethylphosphonate) is an active substance of synthetic origin $[18,19]$ with recognized phytoiatric properties, classified as fungicide allowed in conventional, but not in organic farming (Annex II) [20,21]. After application to the crop, the fosetyl-Al is rapidly degraded to ethyl-hydrogen phosphonate, and then hydrolyzed to phosphonic acid [22], whose salts (i.e., K-phosphite or $\mathrm{NH}_{4}$-phosphite) are allowed in conventional farming as active substance $[23,24]$ and whose MRL in fruits and vegetables is defined by European legislation [23]. Due to its synthetic, non-natural origin, the final Report of 30 April 2014 of the Expert Group for Technical Advice on Organic Production (EGTOP), operating within the Standing Committee on Organic Production-DG Agriculture (COM), suggested to not allow the use of potassium phosphite as plant protection product in organic farming [25].

From 2014, the detection of phosphonic acid residues in organic fruits and vegetables on the EU market has significantly grown, becoming a relevant issue at European level, particularly in relation to organic fruit and vegetables (Table 1).

Table 1. Report of analysis of phosphonic acid found in EU organic fruit and vegetable samples [26]. Only the first ten crops with registered positivity are listed.

\begin{tabular}{ccc}
\hline Crop & $\mathbf{N}^{\circ}$ Analysed Samples & $\begin{array}{c}\text { Samples Positive to } \\
\text { Phosphonic Acid }\end{array}$ \\
\hline Asparagus & 21 & $38 \%$ \\
Wine grape & 21 & $28.6 \%$ \\
Watermelon & 47 & $27.7 \%$ \\
Orange & 36 & $25 \%$ \\
Clementine & 22 & $18.2 \%$ \\
Table grape & 57 & $18 \%$ \\
Potato & 24 & $16.7 \%$ \\
Pepper & 30 & $13 \%$ \\
Pear & 26 & $11.5 \%$ \\
Melon & 24 & $8.3 \%$ \\
\hline
\end{tabular}


In Italy, the D.M. 20/01/2011 n. 309 of Italian Ministry of Agriculture [27] set the maximum residual level " ... for all the plant protection products not allowed in organic farming ... " to $0.01 \mathrm{mg} \mathrm{kg}^{-1}$ in organic fruits and vegetables. This threshold was consistent with the quantification limit (LOQ) for pesticides reported in the "Quick Method for the Analysis of Numerous Highly Polar Pesticides in Foods of Plant Origin via LC-MS/MS Involving Simultaneous Extraction with Methanol (QuPPe-Method, Version 8.1, Method 1.3) adopted by the EU Reference Laboratory for pesticides requiring Single Residue Methods (EURL-SRM) [28], but not for phosphonic acid, which had a corresponding $0.1 \mathrm{mg} \mathrm{kg}^{-1}$ LOQ, ten times higher than the established limit superimposed by the Italian Decree n. 309 [27]. Only recently, a further revision of the same method (QuPPe-PO Method-Met.1.3/1.4/1.5, Version 10, 09.01.2019) allowed to reach a phosphonic acid LOQ of $0.05 \mathrm{mg} \mathrm{kg}^{-1}$ (up to $0.01 \mathrm{mg} \mathrm{kg}^{-1}$ under optimized working conditions and on specific matrices) [29].

The current EU definition of fosetyl-aluminum residue is the "sum of fosetyl, phosphonic acid and their salts, expressed as fosetyl". In Italy, the "Directive for Accreditation Bodies issuing declarations of conformity of organic products to Reg. EC n. 834/2007"-ACCREDIA RT-16 [30] stated that "...the phosphonic acid detection higher than $0.1 \mathrm{mg} \mathrm{kg}^{-1}$, without the simultaneous detection of ethyl-phosphonic acid higher than $0.01 \mathrm{mg} \mathrm{kg}^{-1}$ in organic vegetable and fruit crops, had to be interpreted as a false positive.". Thus, the RT-16 established that presence or absence of ethyl-phosphonic acid was the only discriminant for contesting the use of non-authorized plant protection products, such as fosetyl-aluminum, being not considered the phosphonic acid an evidence of its use. Consequently, organic goods contaminated by phosphonic acid only were not decertified by control bodies, and organic operators not sanctioned anyway. As a matter of fact, in the last five years (2014-2018) the number of contested irregular Italian organic vegetables/fruits in EU by the Organic Farming Information System (OFIS, Reg. (CE) 889/2008) [21] is in the range of 5-20 per year [31].

In 2016, considering the need of the main Italian associations of organic producers to solve the problem of phosphonic acid contamination in organic products, and to verify if the RT-16 interpretation had to be modified, the Office PQAI 1 "Organic production" of the Italian Ministry of Agriculture, Food and Forestry Policies (Mipaaf) funded the BIOFOSF project "Solving phosphite issue in organic fruit and horticultural crops". The objective of the project was to understand if the phosphonic acid residues detected in organic fruit and vegetable crops were due to: i) the not-allowed use of phosphite salts and/or fosetyl-derivates; ii) the presence of phosphite in some organic fertilizers and plant protection products allowed in organic farming; iii) potential long-term contaminations by fosetyl/phosphite in organic fruit plants; iv) an endogenous biosynthesis of phosphite (as phosphonic acid) into the plant organs [32].

The applied participative, multi-actor approach consisted in several in-field case-studies, carried out by both the researchers and organic farmers, aimed at achieving the four objectives, also by studying the dynamic of fosetyl degradation into phosphonic acid in some vegetable and fruit crops, produced under integrated management.

\section{Materials and Methods}

BIOFOSF hypotheses and multi-actor approach-The BIOFOSF project [32] was built to test a set of alternative hypotheses to understand the origin of phosphonic acid (PHY) detected in organic vegetables and fruits, and propose coherent legislative actions, as described in Figure 1.

To test the above reported hypotheses, a participated, multi-actor approach was applied [33]. The project partners were selected with complementary types of knowledge-scientific, practical, legislative-joining forces in the project activities from beginning to end: Federbio, a leading national association of organic and biodynamic operators and member of ACCREDIA (Italian national organization responsible for the Accreditation of Control and Certification Bodies); several consortia of organic vegetables and fruits producers (Agrintesa, Faenza, Italy; Biotropic, Duisburg, Germany; ApoFruit Italia, Forlì-Cesena, Italy); Regional agricultural Advisory Bodies; policy makers from Italian Mipaaf. All the actors were involved in activities planning, allowing to exploit the organic farmers' 
perception and the certification bodies' experience on organic vegetables and fruits phosphonic acid (PHY) contamination.

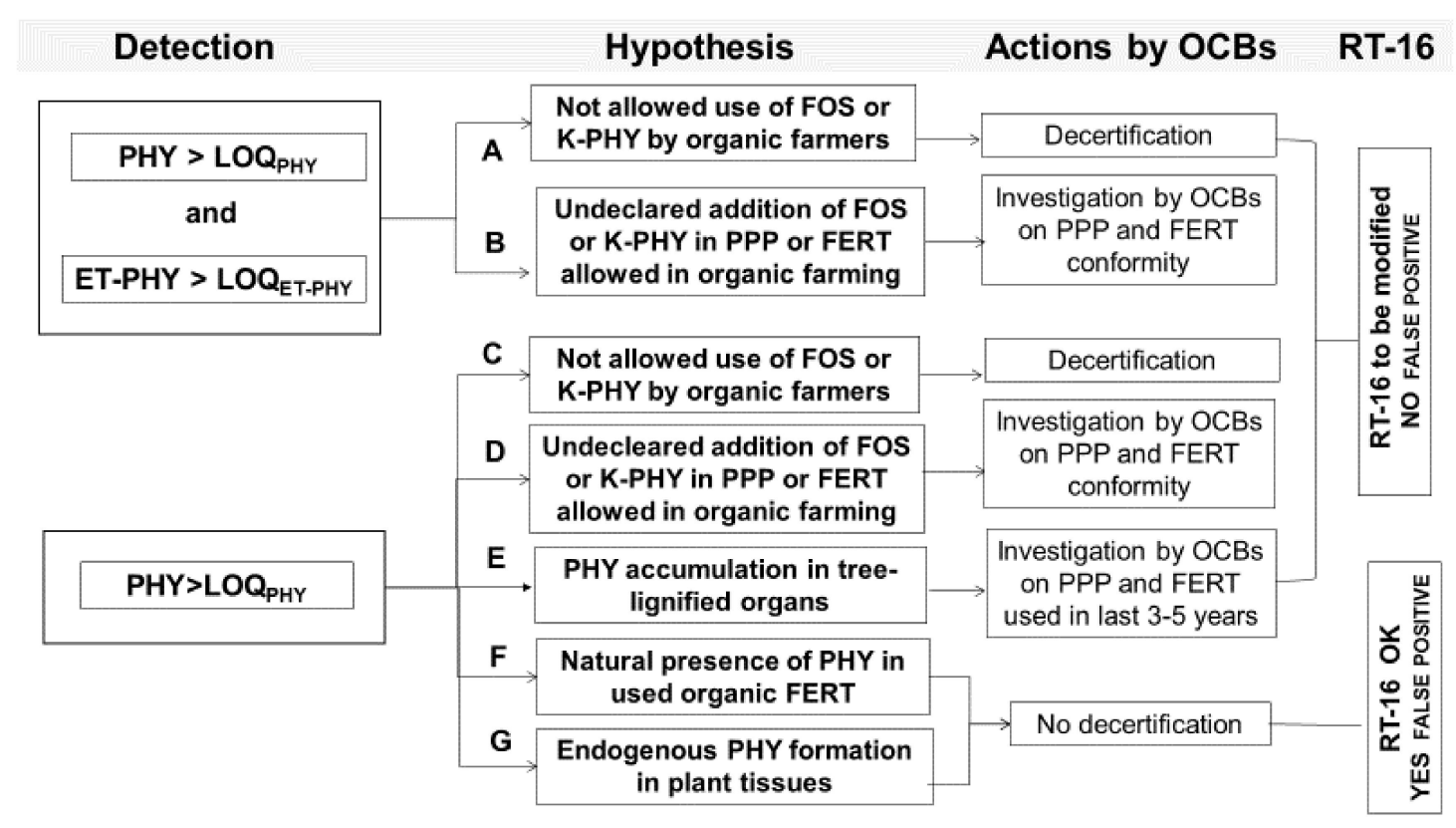

Figure 1. BIOFOSF hypotheses, actions to be carried out by the organic certification bodies (OCBs) and alternative options for RT-16 interpretation [30]. Plant protection products (PPP), Fertilizers (FERT), Fosetyl-Al (FOS), Ethyl-phosphonic acid (ET-PHY), Phosphonic acid (PHY), Potassium phosphite (K-PHY), Quantification limit (LOQ).

At the beginning of the project, the BIOFOSF Advisory Group was formed to promote a constant discussion among researchers, farmers, control bodies, and policy makers on: (i) most relevant crops to be studied; (ii) field designing; (iii) protocols for crop fertilization and protection; (iv) evaluation of results; (v) identification of corrective measures.

Based on the already mentioned EU survey, different field trials were planned on vegetable and fruit crops: two on "highly risky" crops, one on "low risky" one and one on a broad-leaved crop, as follows:

1. one test on potato, aimed at comparing the integrated management (using fosetyl-Al (FOS), hypothesis $\mathrm{A}$, or potassium phosphite (K-PHY), hypothesis $\mathrm{C}$ ) with the organic one (using copper-based plant protection products (PPP), hypotheses B, D), to verify the fate of phosphite in the soil-plant system, the possible role played by the organic fertilizers (hypothesis F), as well as its possible self-production by the crop (hypothesis $\mathrm{G}$ );

2. one case-study (model test) on rocket lettuce to evaluate, after repeated foliar applications of fosetyl-Al, the degradation times and the residuality of phosphonic acid on a broad-leaved crop (hypotheses A, C);

3. a long-term monitoring of two pear orchards to investigate the potential long-term contamination in tree crops (hypothesis E);

4. one case-study on tomato greenhouse cultivation to verify whether organic management determines unjustifiable residues of phosphonic acid in tomato berries (hypotheses B, D, F).

The experimental trials were carried out both in research field stations of the Council for Agricultural Research and Economics (CREA) and in organic producers' farms. 


\subsection{Case-Study on Potato Crop Cultivation}

The first experiment consisted of comparing an organically managed cropping system, using different organic fertilizers (FERT) and the copper oxide as PPP (Ann.s. I and II to Reg. EU n. 889/2008) [21], to another one under integrated management, where the same organic FERT were applied, but FOS or K-PHY were voluntary used as alternative PPP not allowed in organic farming (hypotheses A and C). This was to test if, in the absence of FOS or K-PHY application, the used organic FERT could cause PHY contamination (hypothesis F), or if the crop was able to spontaneously produce PHY in the organic system (hypothesis G). On the other hand, in the integrated system, the persistence of ethyl-phosphonic acid (ET-PHY) and PHY in soil and plant organs after FOS or K-PHY application was evaluated.

In 2016, the demonstrative field trial was carried out at the experimental station of the CREA Research Centre for Cereal and Industrial Crops, located in Budrio ( $44^{\circ} 32^{\prime} \mathrm{N}, 11^{\circ} 32^{\prime} \mathrm{E}, 25 \mathrm{~m}$ a.s.l), in the province of Bologna (Emilia-Romagna Region) with a typical thermo-Mediterranean climate. In 2016, the rainfall distribution throughout the year was uneven, with a total rainfall of $299 \mathrm{~mm}$ during potato growing cycle. The soil was characterized as follows: sandy-loamy texture; moderately calcareous; $\mathrm{pH} 8.1$; organic matter $1.51 \%$; CEC $23.7 \mathrm{meq} / 100 \mathrm{~g}$.

The experiment was carried out on potato (Solanum tuberosum L.), cv. 'Sarpo Mira' (Danespo, DK) in a randomized block design with three replicates under organic management. The 'Sarpo Mira' cultivar was chosen due to its good resistance to late blight under organic open field conditions, so to be grown with low chemical inputs [34]. No herbicide treatments were applied, and weeding was carried out manually by hand-hoeing. A single plot of $28.2 \mathrm{~m}^{2}$ included 125 plants (5 rows with 25 plants each). During the growing period, crop irrigation was carried out with low-volume by a ball-driven sprinkler system.

The organic fertilization was carried out using external inputs allowed in organic farming: hydrolyzed proteins (HYD); hydrolyzed proteins + soft ground rock phosphate (HYD + P); pelleted poultry manure (PM); meat meal (MM). Potassium-magnesium sulfate was added to all the treatments to fulfill the potato nutrient needs. The second factor was the plant protection strategy, performed by splitting each plot into three sub-plots, then treated by foliar spray with: under integrated crop protection, using FOS (400 $\mathrm{g} \mathrm{ha}^{-1}$ per single application, 8 applications); under integrated crop protection, using K-PHY (1.2 $\mathrm{g} \mathrm{ha}^{-1}$ per single application, 8 applications); under organic crop protection, using cuprous oxide $\left(\mathrm{Cu}_{2} \mathrm{O}, 562 \mathrm{~g} \mathrm{ha}^{-1}\right.$ per single application, 4 application). Copper oxide application was reduced respect to the usual agronomic protocol for plant protection (8 applications) to stress the plant and test if the potato had been able to spontaneously produce phosphite (hypothesis G): a "blank" treatment, without any protection or fertilizer treatments, was not considered because this management is not viable to the organic farmers, being our goal to check if the commonly applied organic management could lead to an accumulation of PHY in the crop. The NPK supply per each fertilization/protection treatment is reported in Table 2.

All organic FERT and PPP were analyzed for ET-PHY and PHY content applying the "Quick Method for the Analysis of Numerous Highly Polar Pesticides in Foods of Plant Origin via LC-MS/MS Involving Simultaneous Extraction with Methanol" (QuPPe Method), Version 8.1, Method 1.3 [28], slightly modified for sample preparation: $1.0-5.0 \mathrm{~g}$ of fluid (HYD) or solid fertilizers (PM, MM, P) and PPP $\left(\mathrm{Cu}_{2} \mathrm{O}\right.$, FOS, K-PHY) were extracted with a solution $1 \%$ of formic acid in $\mathrm{MetOH} / \mathrm{H}_{2} \mathrm{O}$, shaked, centrifugated for $5 \mathrm{~min}$ at $\geq 3,000 \mathrm{rpm}$ and then diluted 100-1000 times, depending on the PHI concentration, before LC-MS/MS (ESI-NEG, Agilent Technologies-Model 6495, Santa Clara, United States) analysis [35,36]. Limits of quantifications for PPP and FETT reached were as follows:

- PPP: LOQET-PHY $0.01 \mathrm{mg} \mathrm{kg}^{-1}$ and LOQPHY $0.1 \mathrm{mg} \mathrm{kg}^{-1}$

- FERT: LOQET-PHY $0.1 \mathrm{mg} \mathrm{kg}^{-1}$ and LOQPHY $1.0 \mathrm{mg} \mathrm{kg}^{-1}$ 
Table 2. Plant protection products (PPP) and fertilizers (FERT) applied in 2016. $\mathrm{Cu}_{2} \mathrm{O}$ rate: $562 \mathrm{~g} \mathrm{ha}^{-1}$ per appl.; FOS: $400 \mathrm{~g} \mathrm{ha}^{-1}$ per appl.; K-PHY: $1.187 \mathrm{~g} \mathrm{ha}^{-1}$ per appl. $\mathrm{N}^{\circ}$ of PPP application are reported in parenthesis. NPK supply is reported in $\mathrm{kg} \mathrm{ha}^{-1}$ per year.

\begin{tabular}{|c|c|c|c|c|}
\hline \multirow{2}{*}{ Organic Fertilizers (FERT) * } & \multirow{2}{*}{ Plant Protection Products (PPP) } & \multicolumn{3}{|c|}{ Macronutrients (kg ha $\left.{ }^{-1}\right)$} \\
\hline & & $\mathbf{N}$ & $\mathrm{P}_{2} \mathrm{O}_{5}$ & $\mathrm{~K}_{2} \mathrm{O}$ \\
\hline \multirow{3}{*}{ HYD } & $\mathrm{Cu}_{2} \mathrm{O}(4)$ & 120 & 0 & 300 \\
\hline & FOS (8) & 120 & 0 & 300 \\
\hline & K-PHY (8) & 120 & 0 & 300 \\
\hline \multirow{3}{*}{ HYD + P } & $\mathrm{Cu}_{2} \mathrm{O}(4)$ & 120 & 180 & 300 \\
\hline & FOS (8) & 120 & 180 & 300 \\
\hline & K-PHY (8) & 120 & 180 & 300 \\
\hline \multirow{3}{*}{ PM } & $\mathrm{Cu}_{2} \mathrm{O}(4)$ & 120 & 90 & 300 \\
\hline & FOS (8) & 120 & 90 & 300 \\
\hline & K-PHY (8) & 120 & 90 & 300 \\
\hline \multirow{3}{*}{$\mathrm{MM}$} & $\mathrm{Cu}_{2} \mathrm{O}(4)$ & 120 & 72 & 300 \\
\hline & FOS (8) & 120 & 72 & 300 \\
\hline & K-PHY (8) & 120 & 72 & 300 \\
\hline
\end{tabular}

* HYD: Hydrolyzed proteins; HYD + P: hydrolyzed proteins + soft ground rock phosphate; PM: pelleted poultry manure; MM: meat meal.

The different LOQ obtained for PPP and FERT is due mainly to the presence of organic compounds in the considered FERT, which determined interferences with the PHY and ET-PHY analytes and, thus, reduced the method performance. To evaluate the soil content of fosetyl and phosphonic acid during the experiment, soil was sampled at 0-30 cm depth in each plot [37], at the beginning of the trial (February 2016), 50 days after planting (DAP) (May 2016) and at potato harvest (150 DAP, August 2016). During the growing season, foliage and tubers were harvested and delivered to the lab on independent bags, to determine their ethyl-phosphonic acid (ET-PHY) and the phosphonic acid (PHY) contents. Considering the field trial extension lower than 2000 square meters, after 105 days after planting (105 DAP) and at full canopy senescence (150 DAP), n. 3 sub-samples of potato leaves per sub-plot were collected, then pooled to obtain one sample per sub-plot, corresponding to a total of n.4 fertilization treatments $\times$ n. 3 PPP treatments $\times$ n. 3 blocks $=36$ pooled samples. Potato tubers were sampled at $150 \mathrm{DAP}$, for a total of 36 pooled samples. All samples were analyzed by applying the EU-RL-SRM "Quick Method for the Analysis of Numerous Highly Polar Pesticides in Foods of Plant Origin via LC-MS/MS Involving Simultaneous Extraction with Methanol" (QuPPe Method), Version 8.1, Method 1.3 (2015) [28].

All data of ET-PHY and PHY content in soils, leaves, and tubers were statistically evaluated by a two-way ANOVA, considering as fixed factors the fertilization (FERT) and the plant protection (PPP) treatments (when PHY and ET-PHY content were lower than their LOQ values, in statistical analysis $0.1 \mathrm{mg} \mathrm{kg}^{-1}$ and $0.01 \mathrm{mg} \mathrm{kg}^{-1}$ were used as numerical inputs, respectively). The block was considered as random factor. Mean comparison was carried out according to post hoc Tukey's HSD (honestly significant difference) test using SPSS (IBM Corp., Armonk, NY, USA).

\subsection{Case-Study of Fosetyl-Al Degradation in Rocket Lettuce Cultivation}

In 2017, to evaluate the dynamic of FOS degradation into phosphonic acid (hypotheses A, C), a short-term demonstration test on a broad-leaved vegetable crop was carried out. The research was conducted in open field, at the experimental site of the CREA Research Centre for Agriculture

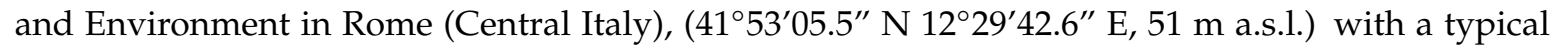
thermo-Mediterranean climate. The absolute annual temperatures range from $3{ }^{\circ} \mathrm{C}$ in winter to $42{ }^{\circ} \mathrm{C}$ in summer. The field test lasted 60 days, from April to May 2017: in this period, temperatures ranged between $16-28{ }^{\circ} \mathrm{C}$ and no rainfalls were recorded during the trial. 
Rocket lettuce was a mixture of Eruca sativa Mill. and Diplotaxis tenuifolia (L.) DC. seedlings, grown in $2 \mathrm{~cm} \times 2 \mathrm{~cm} \times 4 \mathrm{~cm}$ cell packs filled with $60 \%$ perlite $+40 \%$ green compost (according to Annex I of Reg. EC n. 889/2008 [21]. Three treatments with linseed oil before transplanting were carried out for mite control. Plantlets were then transplanted in soil when $6 \mathrm{~cm}$ high ( 3 fully expanded leaves). In the randomized three-block designed system (total area: $\left.36 \mathrm{~m}^{2}\right)$, n. 20 plants per block $\left(2 \mathrm{~m} \times 6 \mathrm{~m}=12 \mathrm{~m}^{2}\right)$ were transplanted in adjacent rows at $50 \mathrm{~cm}$ distance, for a total of $\mathrm{n} .60$ plants. One week before transplanting, fertilization was made applying $\mathrm{MM}$ as organic $\mathrm{N}$-fertilizer at the rate of $80 \mathrm{~kg} \mathrm{~N} \mathrm{ha}^{-1}$. Localized irrigation was carried out by administering $50 \mathrm{~mL}$ per plant after 1,3, 8, and 16 days after transplanting by surface irrigation. Pure FOS was applied in a single rate at a dose of $2.0 \mathrm{~kg} \mathrm{ha}^{-1}$ (i.e., $1000 \mathrm{~L} \mathrm{ha}^{-1}$ ), following the consolidated agronomic protocol. After 1, 7, and 10 days from FOS application, n. 3 rocket foliar samples per each block (i.e., n. 9 foliar samples) were collected and analyzed for ET-PHY and PHY contents applying the QuPPe method [28]. To describe the degradation rate of leaf ET-PHY in PHY in rocket lettuce over time, alternative regression models were used to fit data, considering predicted R-squared values and using the SPSS software package (IBM Corp., Armonk, NY, USA).

\subsection{Long-Term Monitoring of Fruit Tree Contamination}

From 2014, given the use of copper-based products by the farmers for plant protection, a contamination of PHY much greater than $0.01 \mathrm{mg} / \mathrm{kg}$ in different organic pear orchards, located in two Regions of Northern Italy, were found: this study was planned to understand the origin of PHY in fruits and, secondly, verify if a long-term contamination was recognizable in those organic fruit trees (hypothesis E).

From 2015 to 2018, two pear orchards of Agrintesa (Italian growers' cooperative company), the first one located in Cavezzo (MO), Emilia-Romagna Region (EMILIA-R., 44.8 $6.9^{\prime} 41.5^{\prime \prime} \mathrm{N}, 10.9^{\circ} 9.5^{\prime} 71.0^{\prime \prime}$ E), mean annual average temperature $13.2^{\circ} \mathrm{C}$, and the second one in Fogliano Redipuglia (GO), Friuli-Venezia Giulia Region (FRIULI-VG. $45^{\circ} 86.9^{\prime} 84.5^{\prime \prime} \mathrm{N}, 13.4^{\circ} 7.4^{\prime} 49.8^{\prime \prime} \mathrm{E}$ ), mean annual average temperature $14.1^{\circ} \mathrm{C}$, both had converted to organic farming for more than 10 years, and were monitored every year. Two different pear varieties were considered in each orchard ('Abate Fetel' and 'William'), both grafted on 'Abate Fetel': 2 orchards x n. 2 varieties $x 3$ blocks, for a total of $n .12$ pear trees. Trees were selected in a position far from the borders to avoid any "drift effect". On July 2015, 2016, 2017, and 2018, at fruit ripening, in both orchards and on both the 'Abate Fetel' and 'William' varieties, n. 3 fruits per each tree per each block (i.e., n. 9 fruit samples) were collected and analyzed for ET-PHY and PHY contents applying the QuPPe method above mentioned [28]. On November 2017, n. 3 old (3-years old) and n. 3 young (1-year old) branches were sampled from each selected tree, collecting $n$. 3 woody segments of $3 \mathrm{~cm}$ length per branch at $5 \mathrm{~cm}$ distance from previous ramification, for a total of 2 farms $\times 1$ pear trees $\times 3$ blocks $\times 2$ varieties $\times 6$ branches $=72$ samples, each one analyzed for ET-PHY and PHY contents applying the QuPPe method [28], slightly modified for sample preparation: segments of branches were milled to particle sizes $<5.0 \mathrm{~mm}$, extracted with a solution $1 \%$ of formic acid in $\mathrm{MetOH} / \mathrm{H}_{2} \mathrm{O}$, shaken, centrifugated for $5 \mathrm{~min}$ at $\geq 3000 \mathrm{rpm}$ and then diluted 100-1000 times, depending on the PHI concentration, before LC-MS/MS (ESI-NEG Agilent Technologies-Model 6495, Santa Clara, United States) analysis [35,36].

Data of PHY contents in pears of both varieties and in all the orchards were evaluated applying a regression model to fit them, considering predicted R-squared values and using the SPSS (Statistical Package for Social Science) software package (IBM Corp., Armonk, NY, USA).

In addition, to verify the hypothesis $\mathrm{D}, \mathrm{n}$. 22 fertilizers (micronutrient fertilizers, seaweed extracts) and 4 plant protection products (n. 2 copper oxide, n. 3 Bordeaux mixture), repeatedly applied from 2015 to 2017 by the organic farmers on the studied organic pear orchards, were analyzed for ET-PHY and PHY content (QuPPe Method [28], slightly modified as above reported). 


\subsection{Case-Study on Greenhouse Tomato Crop Cultivation}

From the first week of April to mid-August 2016, a farm trial was carried out on organic table tomato (Lycopersicon esculentum), to test whether the organic management usually applied by the involved farmers could cause the phosphonic acid contamination in organic tomato berries. The trials were carried out at a farm located in Buttapietra (Verona, Veneto region, $45^{\circ} 20.0^{\prime} 0.91^{\prime \prime} \mathrm{N}, 11^{\circ} 0.1^{\prime} 21.5^{\prime \prime}$ E), under the supervision of BioTropic, European company specialized in cultivation, import, and export and sale of organic vegetables and fruits. The farm was under organic management for more than 20 years. The soil was characterized as follows: loamy-sandy texture; $\mathrm{pH} 7.7$; organic matter 6,19\%. The mean annual average temperature was $15.2^{\circ} \mathrm{C}$.

The experiment was carried out in two adjacent greenhouse of $60 \mathrm{~m} \times 170 \mathrm{~m}$, each one organized in four tunnels divided into 37 spans of $60 \mathrm{~m} \times 4.6 \mathrm{~m}$, corresponding to $276 \mathrm{~m}^{2}$ per each span (total area: about 1.0 ha). Before tomato planting, in the first greenhouse the soil was fertilized with poultry manure (PM), at the dose of $2000 \mathrm{~kg} \mathrm{ha}^{-1}$, and soft rock phosphate (PK) at $450 \mathrm{~kg} \mathrm{ha}^{-1}$, while in the second greenhouse it was not fertilized (CNT). In both the greenhouses, the soil was mulched with a biodegradable plastic film. Then, plantlets $(7 \mathrm{~cm}$ high) of table tomato "Datterino" Seminis $囚$, var. Cikito (Monsanto Agricoltura Italia Spa-Vegetable Seeds Division, Milan, Italy), were planted into the mulched soil in adjacent rows at $0.8 \mathrm{~m}$ distance, for a total of 1200 plants per tunnel and 4800 plants per greenhouse. During the tomato cropping cycle in fertilized greenhouse, a fluid fertilizer containing $2 \%$ of $\mathrm{Cu}$ and $\mathrm{Zn}(\mathrm{Cu}-\mathrm{Zn})$ at $200 \mathrm{~kg} \mathrm{ha}^{-1}$ and a sugarcane molasses (SM) at $150 \mathrm{~kg} \mathrm{ha}^{-1}$ application $^{-1}$ ( 5 foliar applications) were supplied by fertigation. On the contrary, tomato plants in the CNT greenhouse did not received any fertilization treatment. Neem oil (NO) was used as PPP in all the treatments when needed (2 foliar applications). All organic FERT and PPP were analyzed for ET-PHY and PHY content applying the QuPPe Method [28], as described above.

To evaluate the soil content of fosetyl and phosphonic acid during the experiment, at the beginning of the trial (April 2016) and at tomato harvest (August 2016), ten soil samples at 0-30 cm depth were collected in each greenhouse [37]. In both the fertilized greenhouse and in the CNT one, ten samples of tomato leaves were collected on May 2016. On August 2016, at tomato harvest, ten samples of tomato leaves and ten samples of barriers were collected and delivered to the lab on independent bags, to determine their ethyl-phosphonic acid (ET-PHY) and the phosphonic acid (PHY) contents, applying the method and the statistics reported above.

\section{Results and Discussion}

Hereafter, results coming from the BIOFOSF field case-studies are reported and discussed with respect to the relevant hypotheses.

\subsection{Case-Study on Potato Crop Cultivation}

In Table 3, the PHY and ET-PHY contents in all FERT and PPP used in the potato case-study are reported.

Table 3. PHY ( $\left.\mathrm{mg} \mathrm{kg}^{-1}\right)$ and ethyl-phosphonic acid (ET-PHY) $\left(\mathrm{mg} \mathrm{kg}^{-1}\right)$ content in FERT and PPP applied in the case-study on potato (QuPPe, Version 8.1, Met. 1.3-2015, slightly modified). ${ }^{a}$ LOQPHY in PPP $=0.1 \mathrm{mg} \mathrm{kg}^{-1} ;{ }^{\mathrm{a}} \mathrm{LOQ}_{\mathrm{PHY}}$ in FERT $=1.0 \mathrm{mg} \mathrm{kg}^{-1} .{ }^{\mathrm{b}} \mathrm{LOQ}_{\mathrm{ET}-\mathrm{PHY}}$ in PPP $=0.01 \mathrm{mg} \mathrm{kg}^{-1} ;{ }^{\mathrm{b}}$ $\mathrm{LOQ}_{\mathrm{ET}-\mathrm{PHY}}$ in FERT $=0.1 \mathrm{mg} \mathrm{kg}^{-1}$.

\begin{tabular}{|c|c|c|c|}
\hline Code & Input (FERT/PPP) & Phosphonic Acid (PHY, $\left.\mathrm{mg} \mathrm{kg}^{-1}\right)^{a}$ & Ethyl-Phosphonic Acid(ET-PHY, $\left.\mathrm{mg} \mathrm{kg}^{-1}\right)^{b}$ \\
\hline FOS & Fosetyl Al+Copper oxichloride & 1800 & 441 \\
\hline K-PHY & Potassium phosphite & 555,000 & $<0.01$ \\
\hline $\mathrm{Cu}_{2} \mathrm{O}$ & Copper oxide & $<0.1$ & $<0.01$ \\
\hline HYD & Hydrolysed proteins (animal origin) & $<1.0$ & $<0.1$ \\
\hline PM & Pelletted poultry manure & 1.8 & $<0.1$ \\
\hline MM & Meat meal & $<1.0$ & $<0.1$ \\
\hline $\mathrm{P}$ & Soft ground rock phosphate & $<1.0$ & $<0.1$ \\
\hline $\mathrm{KMg}-\mathrm{S}$ & Potassium-magnesium sulfate & $<1.0$ & $<0.1$ \\
\hline
\end{tabular}


As expected, FOS contained both the PHY (1800 $\left.\mathrm{mg} \mathrm{kg}^{-1}\right)$ and ET-PHY (441 $\left.\mathrm{mg} \mathrm{kg}^{-1}\right)$, while K-PHY only PHY $\left(555,000 \mathrm{~g} \mathrm{~kg}^{-1}\right)$. An amount of $1.8 \mathrm{mg} \mathrm{kg}^{-1}$ of PHY was found in pelleted poultry manure, in absence of contemporary presence of ET-PHY.

The analysis of all collected soil samples gave an ET-PHY content always lower than $0.01 \mathrm{mg} \mathrm{kg}^{-1}$ $\left(<\mathrm{LOQ}_{\mathrm{ET} \text {-PHY }}\right.$ ) and PHY content always lower than $0.1 \mathrm{mg} \mathrm{kg}^{-1}(<\mathrm{LOQ}$ PHY), without any significant difference among treatments, both at the beginning of the trial and at harvesting (data not reported). In Table 4, PHY and ET-PHY content in potato leaves, as affected by FERT and PPP, are reported.

Table 4. Average PHY and ET-PHY content and related standard deviation in potato leaves $\left(\mathrm{mg} \mathrm{kg}^{-1}\right)$, as affected by FERT and PPP treatments. Statistical significance at ${ }^{*} p<0.05,{ }^{* *} p<0.01$ and ${ }^{* * *} p<0.001$ (ANOVA). Different letters represent significant differences (Tukey HSD test for mean comparison). $\mathrm{LOQ}_{\mathrm{PHY}}=0.1 \mathrm{mg} \mathrm{kg}^{-1} ; \mathrm{LOQ}_{\mathrm{ET}-\mathrm{PHY}}=0.01 \mathrm{mg} \mathrm{kg}^{-1}$. NS: not significant.

\begin{tabular}{|c|c|c|c|c|c|}
\hline \multirow{3}{*}{ Organic Fertilizers (FERT) } & \multirow{3}{*}{$\begin{array}{l}\text { Plant Protection } \\
\text { Products (PPP) }\end{array}$} & \multicolumn{4}{|c|}{ LEAVES } \\
\hline & & \multicolumn{2}{|c|}{105 DAP } & \multicolumn{2}{|c|}{150 DAP } \\
\hline & & $\begin{array}{l}\text { Phosphonic Acid } \\
\text { (PHY, } \mathrm{mg} \mathrm{kg}^{-1} \text { ) }\end{array}$ & $\begin{array}{l}\text { Ethyl-Phosphonic Acid } \\
\text { (ET-PHY, } \mathrm{mg} \mathrm{kg}^{-1} \text { ) }\end{array}$ & $\begin{array}{l}\text { Phosphonic Acid } \\
\text { (PHY, } \mathrm{mg} \mathrm{kg}^{-1} \text { ) }\end{array}$ & $\begin{array}{l}\text { Ethyl-Phosphonic Acid } \\
\text { (ET-PHY, } \mathrm{m} \mathrm{kg}^{-1} \text { ) }\end{array}$ \\
\hline \multirow{4}{*}{ HYD } & FOS & $3.9 \pm 1.2 \mathrm{c}$ & $0.06 \pm 0.02 \mathrm{a}$ & $5.3 \pm 1.7 \mathrm{~b}$ & $0.02 \pm 0.02$ \\
\hline & K-PHY & $12.8 \pm 2.2 \mathrm{~b}$ & $<0.01 \mathrm{~b}$ & $10.2 \pm 1.4 \mathrm{a}$ & $0.01 \pm 0.01$ \\
\hline & $\mathrm{Cu} 2 \mathrm{O}$ & $<0.1 \mathrm{~d}$ & $<0.01 \mathrm{~b}$ & $<0.1 \mathrm{c}$ & $<0.01$ \\
\hline & FOS & $3.6 \pm 1.4 \mathrm{c}$ & $0.05 \pm 0.02 \mathrm{a}$ & $4.8 \pm 0.3 \mathrm{~b}$ & $0.01 \pm 0.01$ \\
\hline \multirow{2}{*}{ HYD+P } & K-PHY & $11.2 \pm 1.3 \mathrm{~b}$ & $<0.01 \mathrm{~b}$ & $12.8 \pm 1.7 \mathrm{a}$ & $<0.01$ \\
\hline & $\mathrm{Cu} 2 \mathrm{O}$ & $<0.1 \mathrm{~d}$ & $<0.01 \mathrm{~b}$ & $<0.1 \mathrm{c}$ & $<0.01$ \\
\hline \multirow{3}{*}{ MM } & FOS & $4.6 \pm 0.6 c$ & $0.06 \pm 0.02 \mathrm{a}$ & $5.7 \pm 0.9 \mathrm{~b}$ & $<0.01$ \\
\hline & K-PHY & $11.3 \pm 1.3 \mathrm{~b}$ & $<0.01 \mathrm{~b}$ & $8.2 \pm 2.1 \mathrm{a}$ & $<0.01$ \\
\hline & $\mathrm{Cu} 2 \mathrm{O}$ & $<0.1 \mathrm{~d}$ & $<0.01 \mathrm{~b}$ & $<0.1 \mathrm{c}$ & $<0.01$ \\
\hline \multirow{3}{*}{ PM } & FOS & $4.7 \pm 0.2 c$ & $0.04 \pm 0.01 \mathrm{a}$ & $6.2 \pm 3.0 \mathrm{~b}$ & $0.01 \pm 0.01$ \\
\hline & K-PHY & $15.4 \pm 0.4 \mathrm{a}$ & $<0.01 \mathrm{~b}$ & $11.5 \pm 3.6 \mathrm{a}$ & $<0.01$ \\
\hline & $\mathrm{Cu} 2 \mathrm{O}$ & $<0.1 \mathrm{~d}$ & $<0.01 \mathrm{~b}$ & $<0.1 \mathrm{c}$ & $<0.01$ \\
\hline \multicolumn{2}{|c|}{ FERT-effect (Sig.) } & $*$ & NS & NS & NS \\
\hline \multicolumn{2}{|c|}{ PPP-effect (P) (Sig.) } & $* * *$ & * & $* * *$ & NS \\
\hline \multicolumn{2}{|c|}{ FERT $\times$ PPP (Sig.) } & * & NS & NS & NS \\
\hline
\end{tabular}

The PHY content in potato leaves was significantly affected by FERT only at 105 DAP $(p=0.0361)$, being the highest under PM fertilization, while at harvest no FERT effect was observed on PHY and ET-PHY content. On the contrary, as expected, the FERT did not affect the foliar ET-PHY, either at 105 or 150 DAP. The PPP strongly influenced the foliar PHY at both 105 and 150 DAP, being the highest under K-PHY treatment $(p=0.0008)$. The ET-PHY was influenced only at 105 DAP $(p=0.0425)$, being the highest under FOS treatment, as expected. A slight interaction was observed between FERT and PPP on foliar PHY after 105 DAP $(p=0.0177)$, due to the PM fertilization: anyway, the found PHY increase in potato leaves $\left(15.37 \mathrm{mg} \mathrm{kg}^{-1}\right)$ three months after the animal manure application was not observed at harvest. In Table 5, PHY and ET-PHY contents in potato tubers, as affected by FERT and PPP, are reported.

In tubers, the fertilization influenced only the PHY content after 105 DAP $(P=0.0290)$, being again the highest one under PM treatment. The crop protection management strongly affected PHY content in tubers at $105(p=0.0006)$ and 150 DAP $(p=0.0009)$, but not the ET-PHY one. Again, a significant interaction between FERT and PPP on PHY content in tubers was observed at 105 DAP ( $p=0.0442)$, being the highest under PM treatment.

Results obtained on potato confirmed that, after application of FOS or K-PHY, both the ET-PHY and/or PHY had been always detected in potato leaves and/or tubers, but to a different extent from application. When FOS was added by foliar application, ET-PHY residuals were found in young potato leaves only, being fully converted into PHY during the following 45 days. The absence of ET-PHY residual in young tubers after 105 DAP testifies that the ET-PHY acropetal translocation from leaves to tubers is not relevant in potato plant, while it was observed for PHY in our experiment. Due to the very fast degradation process which occurs on leaves after the foliar spraying of the fosetyl, the detection of PHY residues, in absence of contemporary presence of ET-PHY ones, cannot be considered as a "false positive": thus, it is not possible to exclude the fraudulent application of not allowed PPP and, indeed, the organic product should be decertified (hypothesis A). 
Table 5. Average PHY and ET-PHY content and related standard deviation in potato tubers (in $\mathrm{mg} \mathrm{kg}^{-1}$ ), as affected by FERT and PPP treatments. Statistical significance at ${ }^{*} p<0.05,{ }^{* *} p<0.01$, and ${ }^{* * *} p<0.001$ (ANOVA). Different letters represent significant differences (Tukey HSD test for mean comparison). $\mathrm{LOQ}_{\mathrm{PHY}}=0.1 \mathrm{mg} \mathrm{kg}^{-1} ; \mathrm{LOQ}_{\mathrm{ET}-\mathrm{PHY}}=0.01 \mathrm{mg} \mathrm{kg}^{-1}$. NS: not significant.

\begin{tabular}{|c|c|c|c|c|c|}
\hline \multirow{3}{*}{ Organic Fertilizers (FERT) } & \multirow{3}{*}{$\begin{array}{l}\text { Plant Protection } \\
\text { Products (PPP) }\end{array}$} & \multicolumn{4}{|c|}{ TUBERS } \\
\hline & & \multicolumn{2}{|c|}{105 DAP } & \multicolumn{2}{|c|}{150 DAP } \\
\hline & & $\begin{array}{l}\text { Phosphonic Acid } \\
\text { (PHY, } \mathrm{mg} \mathrm{kg}^{-1} \text { ) }\end{array}$ & $\begin{array}{l}\text { Ethyl-Phosphonic Acid } \\
\text { (ET-PHY, mg kg }\end{array}$ & $\begin{array}{l}\text { Phosphonic Acid } \\
\text { (PHY, } \mathrm{mg} \mathrm{kg}^{-1} \text { ) }\end{array}$ & $\begin{array}{l}\text { Ethyl-Phosphonic Acid } \\
\text { (ET-PHY, } \mathrm{mg} \mathrm{kg}^{-1} \text { ) }\end{array}$ \\
\hline \multirow{4}{*}{ HYD } & FOS & $5.5 \pm 0.3 c$ & $<0.01$ & $5.9 \pm 0.5 b$ & $<0.01$ \\
\hline & K-PHY & $10.2 \pm 2.2 \mathrm{~b}$ & $<0.01$ & $9.8 \pm 1.9 \mathrm{a}$ & $<0.01$ \\
\hline & $\mathrm{Cu} 2 \mathrm{O}$ & $<0.1 \mathrm{~d}$ & $<0.01$ & $<0.1 \mathrm{c}$ & $<0.01$ \\
\hline & FOS & $5.6 \pm 0.4 c$ & $0.01 \pm 0.01$ & $5.7 \pm 1.2 \mathrm{~b}$ & $<0.01$ \\
\hline \multirow{2}{*}{ HYD+P } & K-PHY & $11.1 \pm 1.0 \mathrm{~b}$ & $<0.01$ & $9.7 \pm 0.7 \mathrm{a}$ & $<0.01$ \\
\hline & $\mathrm{Cu} 2 \mathrm{O}$ & $<0.1 \mathrm{~d}$ & $<0.01$ & $<0.1 \mathrm{c}$ & $<0.01$ \\
\hline \multirow{3}{*}{ MM } & FOS & $5.8 \pm 0.1 \mathrm{c}$ & $0.01 \pm 0.01$ & $5.5 \pm 0.4 b$ & $<0.01$ \\
\hline & K-PHY & $9.8 \pm 2.1 \mathrm{~b}$ & $<0.01$ & $10.5 \pm 1.6 \mathrm{a}$ & $<0.01$ \\
\hline & $\mathrm{Cu} 2 \mathrm{O}$ & $<0.1 \mathrm{~d}$ & $<0.01$ & $<0.1 \mathrm{c}$ & $<0.01$ \\
\hline \multirow{3}{*}{ PM } & FOS & $7.2 \pm 1.2 \mathrm{c}$ & $0.01 \pm 0.01$ & $6.7 \pm 0.6 b$ & $<0.01$ \\
\hline & K-PHY & $12.7 \pm 0.7 \mathrm{a}$ & $<0.01$ & $10.4 \pm 0.4 \mathrm{a}$ & $<0.01$ \\
\hline & $\mathrm{Cu} 2 \mathrm{O}$ & $<0.1 \mathrm{~d}$ & $<0.01$ & $<0.1 \mathrm{c}$ & $<0.01$ \\
\hline \multicolumn{2}{|c|}{ FERT-effect (Sig.) } & * & NS & NS & NS \\
\hline \multicolumn{2}{|c|}{ PPP-effect (P) (Sig.) } & $* * *$ & NS & $* * *$ & NS \\
\hline \multicolumn{2}{|c|}{ FERT $\times$ PPP (Sig.) } & $*$ & NS & NS & NS \\
\hline
\end{tabular}

When K-PHY was given to the soil, no PHY was detected in soil at 105 and 150 DAP, this confirmed that the PHY conversion into phosphate promptly occurred in considered soil, probably due to the presence of favorable soil conditions, temperature, and presence of phosphite-metabolizing microbes which promoted PHY biological oxidation process [12]. In fact, thanks to soil microbial activity, PHY oxidation to phosphate in soils lasts approximately 3-4 months, a period which corresponded to the potato growing cycle [15].

Under soil K-PHY treatment, the PHY content significantly increased in young and old potato leaves, evidencing that the PHY was able to basipetally translocate from root system to leaves The interaction observed between PPP and FERT in young leaves and tubers, as a slight increase of PHY in young potato leaves and tubers under PM fertilization and K-PHY supply, not anymore recorded at harvest, suggests that the basipetal translocation of PHY from soil to the different plant organs took place mainly during the first three months of potato grow in field, when the root system is able to uptake more efficiently. Again, when PHY residues are found into tubers, due to the application of not allowed PPP in organic farming (hypothesis C), the organic product should be decertified.

Since no FOS or PHY contamination was found in potato leaves or tubers under $\mathrm{Cu}_{2} \mathrm{O}$ treatments, independently from the applied FERT, we can affirm that no drift effect of FOS/PHY contamination was observed in field. In potato fertilized with PM and using Cu formulate as PPP (hypothesis F), the absence of PHY residues in leaves and tubers either after 105 or after 150 DAP demonstrates that the amount of $1.8 \mathrm{mg} / \mathrm{kg}$ of PHY found in pelleted poultry manure did not cause the tuber contamination and thus the organic products should not be decertified. Actually, some organic fertilizers from animal origin characterized by high amount of phosphate, such as the poultry manure, can contain minimum amounts of PHY: in fact, even if phosphonate derivates (such as aminoethyl phosphonates and phosphonolipids) are not usually supplemented in animal diets, PHY is sometimes detected in feces and in manures, suggesting a microbial origin during the stabilization phase [16]. Anyway, the PHY applied with poultry manure did not cause any residual effect on the crop, likely for the prompt oxidation of PHY into phosphate in the soil [2].

All the other FERT treatments under $\mathrm{Cu}_{2} \mathrm{O}$ protection did not give any effect in terms of PHY contamination of leaves and in tubers during the potato grows, confirming that the plant is not able to synthesize PHY by itself in any plant organs (hypothesis G not confirmed). However, the field trial on tomato, not discussed here, again evidenced that, when FERT and PPP used by the farmer were not contaminated by PHY, the same contaminant was not detected in soil, leaves, and tomato barriers (data not reported). 


\subsection{Case-Study of Fosetyl-Al Degradation in Rocket Lettuce Cultivation}

Foliar contents of PHY, ET-PHY, and FOS, calculated as the sum of foliar ET-PHY and PHY in rocket lettuce, percentages of ET-PHY and PHY degradation/ accumulation and curves obtained by regression models for fitting PHY and ET-PHY data are reported in Figure 2.

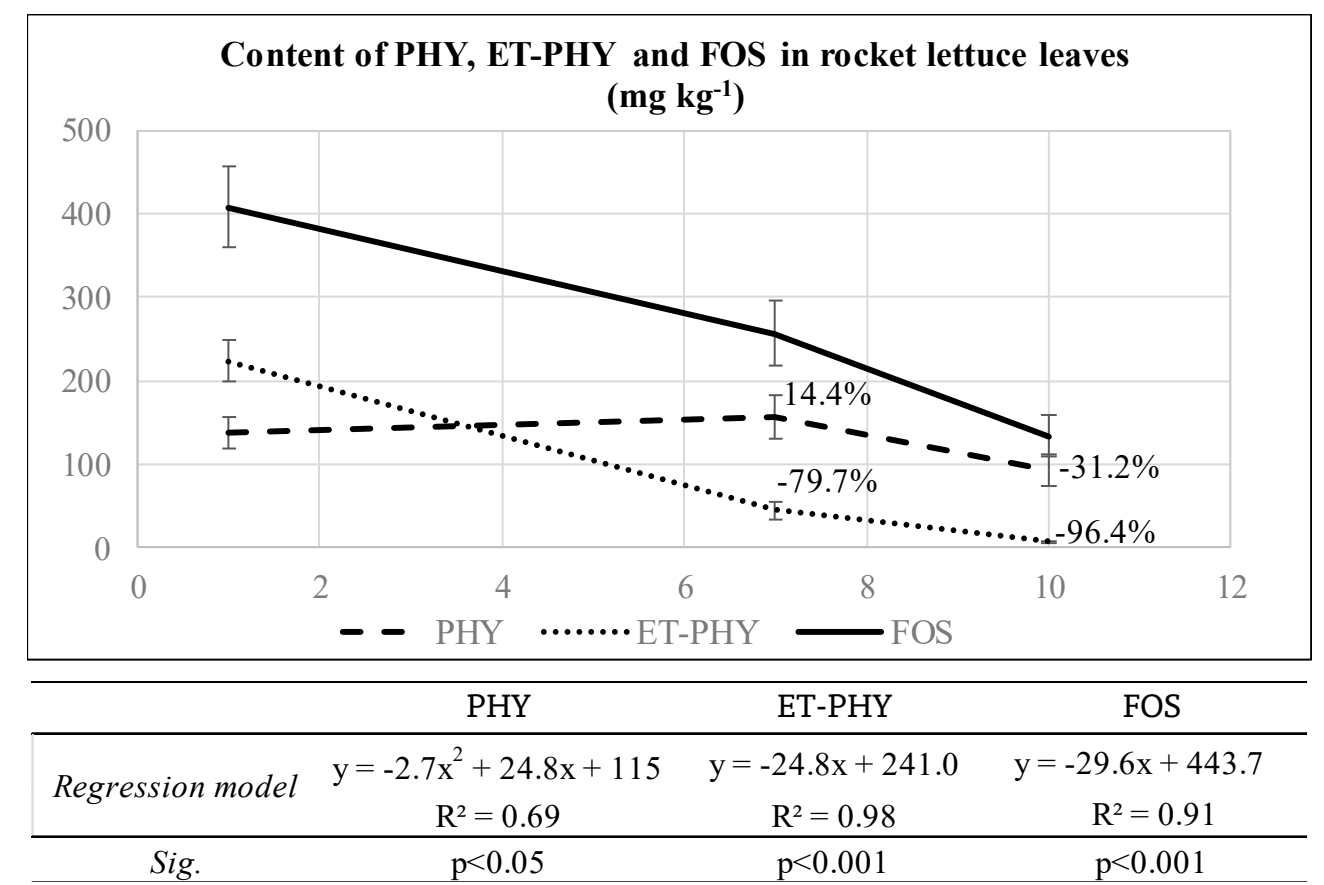

Figure 2. Foliar PHY, ET-PHY, and FOS (as sum of ET-PHY + 1.348 PHY and its salts) recorded in rocket lettuce 1, 7 and 10 days after FOS-Al treatment, percentages of ET-PHY and PHY degradation/accumulation and related regression models for foliar PHY and ET-PHY content $\left(\mathrm{mg} \mathrm{kg}^{-1}\right)$. $\mathrm{LOQ}_{\mathrm{PHY}}=0.1 \mathrm{mg} \mathrm{kg}^{-1} ; \mathrm{LOQ}_{\mathrm{ET}-\mathrm{PHY}}=0.01 \mathrm{mg} \mathrm{kg}^{-1}$.

A fast degradation of FOS was recorded in rocket lettuce, being $79.7 \%$ the foliar degradation of ET-PHY after 7 and $96.4 \%$ after 10 days from FOS treatment. On the opposite, at 7 days from FOS treatment, PHY increased to $14.4 \%$ in respect to the starting value, while after 10 days it decreased by $31.2 \%$. The best regression model to fit data of foliar ET-PHY was a typical linear regression, where the Y-function was the ET-PHY content, and the X-variable was the time (as days after treatment), giving a negative slope (-24.8) and an intercept with the $\mathrm{X}$-axis at 10 days after treatment. This curve showed a good data fit, being $R^{2}$ very high $(0.98$, at $p<0.001)$. Otherwise, the best regression model able to describe the foliar PHY content was a negative quadratic one, where the Y-function was the PHY content and the $\mathrm{X}$-variable was the time, with a first quadratic term negative $(-2.7)$ and the second one positive (24.8). This second order, polynomial curve did not fit at the best the experimental data, even if the $\mathrm{R}^{2}$ was acceptable (0.69). Regression model for foliar FOS was not considered, since FOS content in rocket lettuce leaves was derived by an applied formula, and thus not an independent variable.

After a foliar treatment with fosetyl-Al of this broadleaf species, the ET-PHY degradation was extremely rapid within the first 10 days after phytosanitary treatment, while again the PHY showed a high persistence on foliar apparatus. The degradation kinetics of ET-PHY and PHY showed opposite trends being, as expected, typically linear the first one, and more responsive to a negative quadratic pattern the second one. This suggested that the PHY kinetic curve is the resultant of two opposite, contemporary processes: from one side, the increase of PHY deriving from ET-PHY degradation and, in parallel, the simultaneous decrease of PHY, probably due to its partial oxidation into phosphate during time. 
Ruthbaum and Baille [38] observed that PHY is highly soluble in water and accessible to plants [13]. Based on this high solubility, PHY supplied by foliar spray is rapidly absorbed and translocated within the plant $[39,40]$. The following conversion of PHY to phosphate may result from slow chemical oxidation or by oxidizing bacteria and fungi that have been found living, for example, on citrus and avocado leaves [10-41]: as a matter of fact, there is consistent evidence that PHY is more readily absorbed into plant tissues than phosphate [12]. Anyway, phosphonate oxidation to phosphate should provide a good electron source for microbial energy metabolism, as the electrons are released at a very low redox potential [7]. Some strictly anaerobic, phosphite-oxidizing sulphate-reducing bacteria were found in nature, able to oxidize phosphonate into phosphate [42]. In plant cells, the only way to oxidize the PHY into phosphate to use PHY as a P-source is through the bacterial phosphite dehydrogenase expression, as already found in Arabidopsis and tobacco [43]: this mechanism could be claimed to explain our finding on PHY decrease on rocket leaves.

Again, data confirmed that the PHY detection, without contemporary presence of ET-PHY (hypothesis C), has not to be interpreted as a "false positive", since just after three weeks from foliar application of a fosetyl-derivate, the ET-PHY molecule is not detectable anymore $\left(<0.01 \mathrm{mg} \mathrm{kg}^{-1} \mathrm{after}\right.$ 20 days).

\subsection{Long-Term Monitoring of Fruit Tree Contamination}

In Table 6, the PHY content in fruit, leaves and in 1-year and 3-years old branches collected from organic pear trees of the two considered varieties ('Abate Fetel' and 'William') in both the Italian farms (FRIULI-VG. and EMILIA-R.) are reported.

Table 6. Average PHY content $\left(\mathrm{mg} \mathrm{kg}^{-1}\right)$ and related standard deviation in pear fruits (2015-2018), leaves (2016-2017), 1- and 3-year old branches (2017), as affected by the year (Y-Effect). Levels of statistical significance are: ${ }^{*} p<0.05,{ }^{* *} p<0.01$ and ${ }^{* * *} p<0.001$ (ANOVA). Different letters represent significant differences (Tukey HSD test for mean comparison). $\mathrm{LOQ}_{\mathrm{PHY}}=0.1 \mathrm{mg} \mathrm{kg}^{-1}$ in fruits and leaves; $\mathrm{LOQ}_{\mathrm{PHY}}=0.1 \mathrm{mg} \mathrm{kg}^{-1}$ in branches.

\begin{tabular}{|c|c|c|c|c|c|}
\hline \multicolumn{6}{|c|}{ Phosphonic Acid (PHY) (mg kg-1) } \\
\hline \multirow{2}{*}{ FRIULI FARM } & \multicolumn{4}{|c|}{ cv. Williams' } & \multirow[b]{2}{*}{ Y-Effect } \\
\hline & 2015 & 2016 & 2017 & 2018 & \\
\hline \multirow{6}{*}{$\begin{array}{c}\text { Fruit } \\
\text { Leaves } \\
\text { 1-year branches } \\
\text { 3-year branches }\end{array}$} & $3.5 \pm 0.5 a$ & $1.5 \pm 0.7 \mathrm{~b}$ & $0.3 \pm 0.1 \mathrm{c}$ & $0.41 \pm 0.1 \mathrm{c}$ & $* * *$ \\
\hline & & $0.4 \pm 0.1 \mathrm{a}$ & $0.3 \pm 0.1 b$ & & $*$ \\
\hline & & & $0.4 \pm 0.3$ & & \\
\hline & & & $0.3 \pm 0.2$ & & \\
\hline & \multicolumn{4}{|c|}{ cv. Abate } & \\
\hline & 2015 & 2016 & 2017 & 2018 & Y-Effect \\
\hline Fruit & \multirow{4}{*}{$13.9 \pm 1.2 \mathrm{a}$} & \multirow{4}{*}{$\begin{array}{c}11.2 \pm 0.8 \mathrm{~b} \\
8.7 \pm 0.1 \mathrm{a}\end{array}$} & $0.8 \pm 0.4 \mathrm{c}$ & \multirow{4}{*}{$0.6 \pm 0.2 \mathrm{~d}$} & \multirow{4}{*}{ *** } \\
\hline Leaves & & & $0.6 \pm 0.2 b$ & & \\
\hline 1-year branches & & & $2.6 \pm 0.4$ & & \\
\hline 3-year branches & & & $2.4 \pm 0.2$ & & \\
\hline \multirow{2}{*}{\multicolumn{6}{|c|}{$\begin{array}{c}\text { Phosphonic acid (PHY) }\left(\mathrm{mg} \mathrm{kg}^{-1}\right) \\
\text { cV. Williams' }\end{array}$}} \\
\hline & & & & & \\
\hline FARM & 2015 & 2016 & 2017 & 2018 & Y-Effect \\
\hline Fruit & \multirow[t]{4}{*}{$0.5 \pm 0.2 b$} & $1.4 \pm 0.3 a$ & $0.5 \pm 0.2 b$ & \multirow{4}{*}{$0.12 \pm 0.1 \mathrm{c}$} & ** \\
\hline Leaves & & $0.6 \pm 0.1 \mathrm{a}$ & $0.4 \pm 0.1 \mathrm{~b}$ & & * \\
\hline 1-year branches & & & $0.3 \pm 0.2$ & & \\
\hline \multirow[t]{3}{*}{ 3-year branches } & & & $0.3 \pm 0.2$ & & \\
\hline & \multicolumn{4}{|c|}{ cv. Abate } & \\
\hline & 2015 & 2016 & 2017 & 2018 & Y-Effect \\
\hline Fruit & $3.0 \pm 0.3 \mathrm{a}$ & $1.8 \pm 0.6 \mathrm{~b}$ & $0.2 \pm 0.1 \mathrm{c}$ & $0.1 \pm 0.1 \mathrm{~d}$ & ** \\
\hline Leaves & & $0.4 \pm 0.2 \mathrm{a}$ & $0.1 \pm 0.1 \mathrm{~b}$ & & $* *$ \\
\hline 1-year branches & & & $1.0 \pm 0.3$ & & \\
\hline 3-year branches & & & $0.7 \pm 0.2$ & & \\
\hline
\end{tabular}


Although farmers used only FERT and PPP allowed in organic farming in the last five years, PHY contamination was detected in fruits of both the two pear varieties and in both the farms. The 'Abate Fetel' variety showed higher PHY contamination when compared to 'William' ones. Based on fruit PHY content from 2015 to 2018, a significant decrease of PHY contamination was observed on time, except for 'William' pears from FRIULI-VG. farm, where in 2016 a significant increase of PHY fruit content $\left(1.4 \mathrm{mg} \mathrm{kg}^{-1}\right)$ was found compared to the previous year $\left(0.5 \mathrm{mg} \mathrm{kg}^{-1}\right)$. In 2016 and 2017, a PHY contamination was recorded in leaves, while in 2017 also in young and old pear tree branches, evidencing the ability of pear trees of stocking the PHY for several years in old, lignified plant organs. Regression analysis of PHY content in pears recorded from 2015 to 2018 showed that the exponential equations were the best models able to fit the PHY content decrease in fruits, especially in ER orchards, independent from the tree varieties (Table 7).

Table 7. Exponential model applied to PHY content $(\mathrm{mg} / \mathrm{kg})$ in pear fruits of 'William' and 'Abate Fetel' from FRIULI-VG. and EMILIA-R. farms. Days $\mathrm{y}_{\mathrm{y}}=0.1$ and Days $\mathrm{y}=0.05$ : days for reaching 0.1 or $0.05 \mathrm{mg} \mathrm{kg}^{-1}$ of PHY in fruits; Years $\mathrm{y}_{=0.1}$ and Years $\mathrm{y}_{\mathrm{y}}=0.05$ : years for reaching 0.1 or $0.05 \mathrm{mg} \mathrm{kg}^{-1}$ of PHY in fruits.

\begin{tabular}{cccccccc}
\hline PHY (mg/kg) & Regression Model & $\mathbf{R}^{\mathbf{2}}$ & Sig. & Days $_{\mathbf{y}=\mathbf{0 . 1}}$ & Years $_{\mathbf{y}=\mathbf{0 . 1}}$ & Days $_{\mathbf{y}=\mathbf{0 . 0 5}}$ & Years $_{\mathbf{y}=\mathbf{0 . 0 5}}$ \\
\hline William' (FRIULI-VG.) & $\mathrm{y}=2.9757 \mathrm{e}^{-0.002 \mathrm{x}}$ & 0.796 & $p>0.01$ & 1690 & 5 & 2043 \\
Abate Fetel' (FRIULI-VG.) & $\mathrm{y}=18.161 \mathrm{e}^{-0.003 \mathrm{x}}$ & 0.871 & $p>0.01$ & 1734 & 5 & 5 \\
William' (EMILIA-R.) & $\mathrm{y}=1.5156 \mathrm{e}^{-0,003 \mathrm{x}}$ & 0.988 & $p>0.001$ & 906 & 2 & 1965 & 5 \\
Abate Fetel' (EMILIA-R.) & $\mathrm{y}=3.8306 \mathrm{e}^{-0.003 \mathrm{x}}$ & 0.954 & $p>0.001$ & 1215 & 3 & 1446 \\
\hline
\end{tabular}

The analysis of the used micronutrient fertilizers, seaweed extracts, $\mathrm{Cu}$-oxichloride, and Bordeaux mixture, applied in the three years $(2015,2016$, and 2017) of trials on pear trees by the farmers gave unexpected results: even if all were regularly registered as allowed in organic farming (Annex I and II to the Reg. EC n.889/2008) [21], five of them contained relevant amount of PHY and, sometimes also of ET-PHY (Table 8).

Table 8. ET-PHY and PHY content ( $\left.\mathrm{mg} \mathrm{kg}^{-1}\right)$ in FERT and PPP applied on pear trees from 2015 to 2017 by farmers (QuPPe, Version 8.1, Met. 1.3-2015, slightly modified). ${ }^{a} \mathrm{LOQ}_{\mathrm{ET}-\mathrm{PHY}}$ in $\mathrm{PPP}=0.01 \mathrm{mg} \mathrm{kg}^{-1}$;

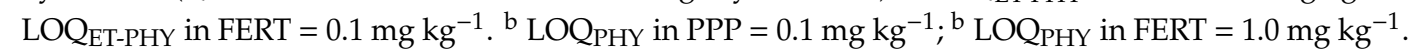

\begin{tabular}{ccc}
\hline Input & ET-PHY $^{\mathbf{a}}(\mathbf{m g} / \mathbf{k g})$ & PHY $\left.^{\mathbf{b}} \mathbf{( m g} / \mathbf{k g}\right)$ \\
\hline Copper oxychloride & 656.0 & 0.6 \\
Bordeaux mixture & 1.5 & - \\
Micronutrient fertilizer & - & 28.0 \\
Seaweed extracts (1) & - & 7.0 \\
Seaweed extracts (2) & - & 37.0 \\
\hline
\end{tabular}

Based on previous literature on PHY persistency in tree crops [14,41-44], we carried out this study on pear trees to understand the origin of PHY contamination on organic fruits: we found a PHY contamination in fruits, leaves, but unexpectedly also in young and old branches of pear trees, independently from the orchard location and the pear tree variety. This evidenced a contamination apparently not justifiable by the organic management applied in ER and FR farms, both converted into organic ones from more than ten years. The evaluation of the PPP and FERT applied to pear trees in ER and FR orchards from 2015 to 2017 by the farmers confirmed that all the technical means were allowed in organic farming (Annexes I and II to the Reg. EC n.889/2008) [21], but three FERT contained PHY between 7.0 and $37 \mathrm{mg} \mathrm{kg}^{-1}$, and two Cu-based PPP contained relevant amount of both PHY and ET-PHY (up to $656 \mathrm{mg} \mathrm{kg}^{-1}$ ). Considering that at least three treatments/year with Bordeaux mixture were carried out on pear trees every year, reasonably the PPP and FERT treatments were the cause of the PHY residues detected in organic pears (hypothesis D). Previous studies on PHY contamination due to foliar FOS application on apples showed that residual PHY level in fruits 
was positively correlated with the amount of PHY present in the applied FOS or K-PHY formulates, the plant size and yield [45]. The same authors observed that PHY residuals were accumulated in different plant organs, such as the roots and buds of the apple tree. Our study on pear trees showed that the young, and even the old branches, acted as a physiological sink of PHY, from which during the growing season it translocated to leaves and then fruits for reproductive proposals (hypothesis E). The PHY storage in pear tree branches, and the following PHY decreasing observed in pear fruits during the four years of monitoring suggested that, when fruit trees are contaminated, three years of organic conversion period could be not always enough to guarantee the respect of MLR for pesticide residues, as established by the Italian DM n. 309/2011 [27]. In fact, it can be stored and re-mobilized by the plant, thus prolonging in the following seasons the residual effect of the FOS/PHY treatments and generating a long-term contamination of fruits which could request more than 5 years to repristinate an uncontaminated system [45].

Starting from trendlines describing the PHY content in pears, we calculated the corresponding theoretical periods (in days or in years) needed to reach a fruit PHY content equal to quantification limit, that means: $\mathrm{y}=0.1 \mathrm{mg} \mathrm{kg}^{-1}$ as LOQPHY (QuPPe Method 1.3 ver.8.1); $\mathrm{y}=0.05 \mathrm{mg} \mathrm{kg}^{-1}$ as LOQPHY (QuPPe Method 1.3, ver.10, Table 7) [29]. In studied orchards, the tree decontamination could need from 2 to 5 years to reach PHY $<0.1 \mathrm{mg} \mathrm{kg}^{-1}$ and from 3 to 5 years to reach the PHY $<0.05 \mathrm{mg} \mathrm{kg}^{-1}$ in fruits, depending on the initial value of the PHY detected in the fruits and lignified organs of trees, but also by the different varieties. This is key for defining MRL of PHY after 3 years of conversion period in organic orchards, especially if they were treated with FOS or K-PHY under conventional management, or in case of accidental contamination by external inputs. With few exceptions, at least five years of conversion period seem an adequate period to assure the complete PHY decontamination of a previously contaminated organic orchard. Anyway, it is important to carry out a preliminary monitoring at the beginning of the organic conversion by using young branches as testing materials for early evaluation of PHY residue level in such orchards. This monitoring would allow to take as soon as possible appropriate measures to reduce undesired contamination by the farmers, for example by selecting FERT and PPP which can guarantee the absence of PHY in their formulation.

\subsection{Case-Study on Tomato Greenhouse Cultivation}

The analysis of the FERT and PPP used in the greenhouse trial on tomato showed that PM, PK, Cu-Zn fertilizers, and NO did not contain either FOS $\left(<0.01 \mathrm{mg} \mathrm{kg}^{-1}\right)$ or PHY $\left(<0.1 \mathrm{mg} \mathrm{kg}^{-1}\right)$. Unexpectedly, $1.1 \mathrm{mg} \mathrm{kg}^{-1}$ of PHY was found in SM, while FOS was absent $\left(<0.1 \mathrm{mg} \mathrm{kg}^{-1}\right)$.

Soils sampled in the two greenhouses at the beginning and at the end of the trial gave no contamination by FOS $\left(<0.1 \mathrm{mg} \mathrm{kg}^{-1}\right)$ and PHY $\left(<1.0 \mathrm{mg} \mathrm{kg}^{-1}\right)$, independent from the soil fertilization. Similarly, all tomato leaves and berries sampled did not show any FOS $\left(<0.01 \mathrm{mg} \mathrm{kg}^{-1}\right)$ and PHY $\left(<0.1 \mathrm{mg} \mathrm{kg}^{-1}\right)$ residues in both the compared unfertilized/fertilized systems.

As already observed on potato, the absence of PHY also in the CNT tomatoes confirmed again that vegetable plants were not able to produce PHY by ourselves (hypothesis $\mathrm{G}$ ). It should be remarked the SM, positive to PHY, even though applied several times on tomato by fertigation, did not determine any residue neither in tomato leaves nor in harvested berries. This could be due to low PHY content found in commercial products: in fact, considering 4800 tomato plants in each greenhouse, the five application of SM corresponded to $750 \mathrm{~kg} \mathrm{ha}^{-1}$ and to $0.15 \mathrm{~g}_{\text {plant }}{ }^{-1}$ of SM. Since SM contained $1.1 \mathrm{mg} \mathrm{kg}^{-1}$ of PHY, each tomato plant received approximately $0.17 \mathrm{mg}$ of PHY during the growing cycle. This PHY supplementation by fertigation was evidently not able to induce contamination in the marketable product: this is in line with the previous results obtained in potato trial, where PM, containing PHY, was applied. These findings evidenced that the application of organic fertilizers cannot be considered the cause of PHY residues detection in organic vegetables, making null the F hypothesis, at least when the recorded PHY content in organic fertilizers is lower than $2 \mathrm{mg} \mathrm{kg}^{-1}$. 


\section{Conclusions}

The BIOFOSF project was set to understand the origin of PHY contamination in vegetable and fruit crops, and if a modification of the ACCREDIA RT-16 Directive was needed.

The comparison of potato production under integrated vs. organic management showed that, after FOS or K-PHY treatments, only PHY residues were detected in tubers at harvest. The fertilization with poultry manure to soil did not determine any contamination on potatoes, although the PHY content detected in the organic fertilizer. At the same time, fertigation with sugarcane molasses confirmed that the organic fertilizers cannot be considered the origin of PHY contamination of organic vegetables, at least when they contain $\mathrm{PHY}<2 \mathrm{mg} \mathrm{kg}^{-1}$. The experiment on rocket lettuce confirmed that FOS was rapidly degraded into PHY, as observed after repeated foliar applications. In addition, a long-term PHY contamination was verified in pear trees, due to the ability of PHY to be stored in trees' woody organs, and then translocated from the leaves to the fruits.

Summarizing, the PHY residues detected in organic vegetables and fruits sampled within the BIOFOSF project field trials were always due to voluntary application of FOS or PHY-K or unaware supply by external inputs containing undeclared ET-PHY and/or PHY, being not found evidences of endogenous production of PHY in the tested crops. The use of fertilizers and copper-based products contaminated by high amounts of PHY and/or ET-PHY caused a long-term contamination in tree crops, which needs several years to reach a PHY content close to LOQ ${ }_{\mathrm{PHY}}$ in marketable fruits.

Based on BIOFOSF results, from 2018 in Italy, the interpretation of "false positive" in absence of ET-PHY is not anymore acceptable for vegetables and fruit crops containing PHY higher than its limit of quantification and must induce to a detailed investigation of its origin by the control bodies. Given the detection of PHY found in some fertilizers and PPPs analyzed within the BIOFOSF project, a deep revision of the control procedures applied to contrast frauds in fertilizers/PPP production is necessary, together with a temporary increase of the admissible PHY threshold for considering the long-term contamination found in tree crops.

At the end, we underline that the BIOFOSF project can be considered as a successful example of a multi-actor project, where the stakeholders have been an active part not only in the experimental activities, but also in the construction of the hypotheses within the project, their verification and results interpretation, then playing a key role in supporting researchers and policy makers on defining legislative proposals on PHY contamination in organic products.

Author Contributions: Conceptualization, A.T.; Data curation, A.T., B.P., V.B. and D.F.; Formal analysis, A.T. and V.B.; Investigation, B.P., V.B., G.R., I.S., C.B., M.F. and M.B.; Methodology, A.T., B.P., G.R., I.S., C.B. and L.L.; Project administration, A.T.; Resources, F.R. and G.M.; Writing-original draft, A.T. All authors have read and agreed to the published version of the manuscript.

Funding: The BIOFOSF project "Solving phosphite issue in organic fruit and horticultural crops" was funded by the PQAI 1 Office “Organic production" (Ministry Decree n. 9825 of 30.12.2015 of the Italian Ministry of Agriculture, Food and Forestry Policies, Mipaaf).

Acknowledgments: Many special thanks are due to the PQAI 1 "Organic farming" Office of the Italian Ministry of Agriculture (Mipaaf) for funding the BIOFOSF project and supporting the dissemination of collected data within SINAB website: http://www.sinab.it/ricerca/\%E2\%80\%9Cstrumenti-la-risoluzione-dell\%E2\%80\% 99emergenza-\%E2\%80\%9Cfosfiti\%E2\%80\%9D-nei-prodotti-ortofrutticoli-biologici\%E2\%80\%9D-.Thank are due to GREIT ANALYTICAL LABORATORIES for carrying out determinations of phosphonic acid and ethyl-phosphonic acid in leaves, vegetables, fruits, fertilizers and plant protection products within the BIOFOSF project and to ASSOFERTILIZZANTI for supplying fertilizers applied by CREA in the field trials.

Conflicts of Interest: The authors declare no conflict of interest.

\section{Abbreviations}

Agrotechnical terms and related abbreviations. 


$\begin{array}{ll}\text { Agrotechnical Terms } & \text { Abbreviation } \\ \text { Fertilizers } & \text { FERT } \\ \text { Plant protection products } & \text { PPP } \\ \text { Soft ground rock phosphate } & \text { P } \\ \text { Fosetyl-Al } & \text { FOS } \\ \text { Ethyl-phosphonic acid } & \text { ET-PHY } \\ \text { Phosphonic acid } & \text { PHY } \\ \text { Potassium phosphite } & \text { K-PHY } \\ \text { Hydrolyzed proteins } & \text { HYD } \\ \text { Poultry manure } & \text { PM } \\ \text { Meat meal } & \text { MM } \\ \text { Potassium-magnesium sulfate } & \text { KMg-S } \\ \text { Copper and zinc fertilizer } & \text { Cu-Zn } \\ \text { Soft rock phosphate } & \text { PK } \\ \text { Sugarcane molasses } & \text { SM } \\ \text { Neem oil } & \text { NO } \\ \text { Maximum residual level } & \text { MRL } \\ \text { Quantification limit } & \text { LOQ } \\ \text { Days after planting } & \text { DAP } \\ \text { Organic certification bodies } & \text { OCBs }\end{array}$

\section{References}

1. MacIntire, W.H.; Winterberg, S.H.; Hardin, L.J.; Sterges, A.J.; Clements, L.B. Fertilizer evaluation of certain phosphorus, phosphorous and phosphoric materials by means of pot cultures. Agron. J. 1950, 42, 543-549. [CrossRef]

2. Adams, F.; Conrad, J.P. Transition of phosphite to phosphate in soils. Soil Sci. 1953, 75, 361-371. [CrossRef]

3. Casida, L.E., Jr. Microbial oxidation and utilization of orthophosphite during growth. J. Bacteriol. 1960, 80, 237-241. Available online: https://www.ncbi.nlm.nih.gov/pmc/articles/PMC278847/pdf/jbacter00482-0119. pdf (accessed on 16 March 2020). [CrossRef] [PubMed]

4. Malacinski, G.; Konetzka, W.A. Bacterial oxidation of orthophosphate. J. Bacteriol. 2005, 91, 578-582. Available online: https://www.ncbi.nlm.nih.gov/pmc/articles/PMC314897/ (accessed on 16 March 2020). [CrossRef]

5. Morton, S.C.; Edwards, M. Reduced Phosphorus Compounds in the Environment. Crit. Rev. Environ. Sci. Technol. 2005, 35, 333-364. [CrossRef]

6. Metcalf, W.W.; van der Donk, W.A. Biosynthesis of phosphonic and phosphinic acid natural products. Annu. Rev. Biochem. 2009, 78, 65-94. [CrossRef]

7. Varadarajan, D.K.; Karthikeyan, A.S.; Matilda, P.D.; Raghothama, K.G. Phosphite, an analog of phosphate, suppresses the coordinated expression of genes under phosphate starvation. Plant Physiol. 2002, 129, 1232-1240. [CrossRef]

8. Danova-Alt, T.; Dijema, C.; Dewaard, P.; Kock, M. Transport and compartmentation of phosphite in higher plant cells-kinetic and P nuclear magnetic resonance studies. Plant Cell Environ. 2008, 31, 1510-1521. [CrossRef]

9. Fenn, M.E.; Coffey, M.D. Antifungal activity of fosetyl-Al and phosphorous acid. Phytopathology 1984, 74, 606-6011. Available online: https://www.fs.fed.us/psw/publications/fenn/captured/psw_1984_fenn021. pdf (accessed on 16 March 2020). [CrossRef]

10. Orbovic, V.; Syvertsen, J.P.; Van Clef, D.L.; Graham, J.H. Citrus deedling growth and susceptibility to root rot as affected by phosphite and phosphate. J. Plant Nutr. 2008, 31, 774-787. [CrossRef]

11. Moor, U.; Põldma, P.; Tõnutare, T.; Karp, K.; Starast, M.; Vool, E. Effect of phosphite fertilization on growth, yield and fruit composition of strawberries. Sci. Hortic. 2009, 119, 264-269. [CrossRef]

12. Lovatt, C.J.; Mikkelsen, R.L. Phosphite fertilizers: What are they? Can you use them? What can they do? Better Crops 2006, 4, 11-13. Available online: https://www.spectrumanalytic.com/support/library/pdf/ Phosphite_Fertilizers_What\%20are\%20they.pdf (accessed on 16 March 2020). 
13. Jost, R.; Pharmawati, M.; lapis-Gaza, H.R.; Rossing, C.; Berkowitz, O.; Lambers, H.; Finnegan, P.M. Differentiating phosphate-dependent and phosphate-independent systemic phosphate-starvation response networks in arabidopsis thaliana through the application of phosphite. J. Exp. Bot. 2015, 66, 2501-2514. [CrossRef] [PubMed]

14. Kelderer, M.; Matteazzi, A.; Casera, C. Degradation behaviour of potassium K-phosphite in apple trees. In Proceedings of the Ecofruit-13th International Conference on Cultivation Technique and Phytopathological Problems in Organic Fruit-Growing, Weinsberg, Germany, 18-20 February 2008; pp. 59-61.

15. Gómez-Merino, F.C.; Trejo-Téllez, L.I. Biostimulant activity of phosphite in horticulture. Sci. Hortic. 2015, 196, 82-90. [CrossRef]

16. Toor, G.S.; Cade-Menun, B.J.; Simsa, J.T. Establishing a Linkage between Phosphorus Forms in Dairy Diets, Feces, and Manures. Am. Soc. Agron. 2004, 34, 1380-1391. [CrossRef]

17. Giles, C.D.; Cade-Menun, B.J. Phytate in Animal Manure and Soils: Abundance, Cycling and Bioavailability. In Applied manure and nutrient chemistry for sustainable agriculture and environment; Springer: Berlin, Germany, 2014; ISBN 978-94-017-8806-9.

18. Magarey, P.A.; Wachtel, M.F.; Newton, M.R. Evaluation of phosphonate, fosetyl-Al and several phenylamide fungicides for post-infection control of grapevine downy mildew caused by Plasmopara viticola. Australasian Plant Pathol. 1991, 20, 34-40. [CrossRef]

19. Miles, C.J.; Yanagihara, K.H. Analysis of Fungicides Residues in Vegetables and Vegetable Production. In Vegetables and Vegetable Products; Linskens, H.F., Jackson, J.F., Eds.; Springer Science \& Business Media: Berlin, Germany, 2012; pp. 73-94.

20. Regulation (EC) N. 1107/2009 of the European Parliament and of the Council of 21 October 2009 Concerning the Placing of Plant Protection Products on the Market and Repealing Council Directives 79/117/EEC and 91/414/EEC, OJ L 309, 24.11.2009. Available online: https://eur-lex.europa.eu/eli/reg/2009/1107/oj (accessed on 16 March 2020).

21. Regulation (EC) N. 889/2008 of the Parliament and the Council Laying down Detailed Rules for the Implementation of Council Regulation (EC) No 834/2007. 12/11/2018. Available online: https://eur-lex.europa. eu/legal-content/EN/TXT/?uri=CELEX\%3A32008R0889 (accessed on 16 March 2020).

22. EFSA. Reasoned Opinion on the Review of the Existing Maximum Residual Levels (MRLs) for Fosetyl According to Article 12 of Regulation (EC) No 396/2005. EFSA J. 2014, 12.

23. SANCO/10416/2013, Review report for the active substance disodium phosphonate finalised in the Standing Committee on the Food Chain and Animal Health at its meeting on 16 July 2013 in view of the approval of disodium phosphonate as active substance in accordance with Regulation (EC) No 1107/2009. Available online: https://ec.europa.eu/food/plant/pesticides/eu-pesticides-database/public/?event=activesubstance. detail\&language $=E N \&$ selectedID $=1267$ (accessed on 16 March 2020).

24. Regulation (EC) N. 832/2013 (Dossier Complete 08/953/EC, Disodium Phosphonate). Available online: https://eur-lex.europa.eu/legal-content/EN/ALL/?uri=CELEX:32007D0442 (accessed on 16 March 2020).

25. Speiser, B.; Tamm, L. Could phosphite be a new fungicide for organic farming? N. Ag. Int. $2007,26$. Available online: https://orgprints.org/12817/ (accessed on 16 March 2020).

26. Kimmel, T.; Arp, K. Analysis of phosphonic acid in samples of organic fruits and vegetables; BNN: Tokyo, Japan, 2016.

27. D.M. n. 309 of 13/01/2011, Mipaaf. Accidental and Technically Unavoidable Contamination of Plant Protection Products in Organic Agriculture. Available online: https://www.politicheagricole.it/flex/cm/pages/ ServeBLOB.php/L/IT/IDPagina/4850 (accessed on 16 March 2020).

28. Quick Method for the Analysis of Numerous Highly Polar Pesticides in Foods of Plant Origin via LC-MS/MS Involving Simultaneous Extraction with Methanol (QuPPe- Method), Met 1.3, Version 8.1, EU Reference Laboratory for pesticides requiring Single Residue Methods (EURL-SRM). 2015. Available online: https: //www.eurl-pesticides.eu/library/docs/srm/meth_QuPPe.pdf (accessed on 16 March 2020).

29. Quick Method for the Analysis of Numerous Highly Polar Pesticides in Foods of Plant Origin via LC-MS/MS Involving Simultaneous Extraction with Methanol (QuPPe-Method)-I Food of Plant Origin (QuPPe-PO-Method), Met. 1.3, Version 10, EU Reference Laboratory for pesticides requiring Single Residue Methods (EURL-SRM). 2019. Available online: https://www.eurl-pesticides.eu/userfiles/file/EurlSRM/meth_QuPPe-PO_EurlSRM.pdf (accessed on 16 March 2020). 
30. ACCREDIA RT-16 Technical Regulation, 05/11/2018 Directives for Accreditation of Bodies Issuing Declarations of Conformity of Organic Products and Foodstuffs according to EC Regulations n. 834/2007 and Following Integrations and Modifications. Rev.4. 2016. Available online: https://www.accredia.it/2016/08/04/04-08-2016-nuova-revisione-del-regolamento-tecnico-accrediart-16-per-gli-organismi-di-controllo-delle-produzioni-biologiche/ (accessed on 16 March 2020).

31. Trinchera, A.; Lazzeri, L.; Roccuzzo, G.; Parisi, B.; Baratella, V.; Riva, F.; Ferlito, F.; Bazzocchi, C.; Fichera, D.; Soave, I.; et al. Solving phosphite issue in organic fruit and horticultural crops: Research outcomes and policy strategies. In Proceedings of the BIOFACH2018, Nuremberg, Germany, 14-17 February 2018.

32. Trinchera, A.; Roccuzzo, G.; Lazzeri, L.; Bazzocchi, C. The BIOFOSF Project: Tools for Solving the "Phosphite" Issue in Organic Fruit and Vegetables. SINAB-National Information System on Organic Agriculture. 2016. Available online: http://www.sinab.it/ricerca/\%E2\%80\%9Cstrumenti-la-risoluzione-dell $\%$ E2\%80\% 99emergenza-\%E2\%80\%9Cfosfiti\%E2\%80\%9D-nei-prodotti-ortofrutticoli-biologici\%E2\%80\%9D- (accessed on 16 March 2020).

33. European Commission-EIP-AGRI-Agriculture and Innovation. Horizon 2020 Multi-Actor Projects. 2017, p. 1. Available online: https://ec.europa.eu/eip/agriculture/sites/agri-eip/files/eip-agri_brochure_multi-actor_ projects_2017_en_web.pdf (accessed on 13 March 2020).

34. Rietman, H.; Bijsterbosch, G.; Cano, L.M.; Lee, H.R.; Vossen, J.H.; Jacobsen, E.; Visser, R.G.; Kamoun, S.; Vleeshouwers, V.G. Qualitative and quantitative late blight resistance in the potato cultivar Sarpo Mira is determined by the perception of five distinct RXLR effectors. Mol. Plant Microbe Interact. 2012, 25, 910-919. [CrossRef]

35. Greit Analytical Laboratories. EU Reference Laboratories for Residues of Pesticides for organic products by the Italian Ministry of Agricultural Food and Forestry Policies (Mipaaf). 2019. Available online: https: //www.politicheagricole.it/flex/cm/pages/ServeBLOB.php/L/IT/IDPagina/10043 (accessed on 16 March 2020).

36. Bundesverbant Naturkost Naturvaren. EU Reference Laboratories for Residues of Pesticides, Contaminants and Dioxins (Approved Food Groups B1-B4 Are Listed below the Contact Details of Each Lab). 2019. Available online: https://n-bnn.de/en/quality-affairs/approved-labs (accessed on 16 March 2020).

37. G.U. Suppl. Ord. n.248 21/10/1999, D.M 13/09/1999 “Official Methods for Soil Chemical Analysis". Available online: https://www.gazzettaufficiale.it/eli/id/1999/10/21/099A8497/sg (accessed on 16 March 2020).

38. Ruthbaum, H.P.; Baille, W.J.H. The use of red phosphorus as a fertilizer. Part 4. Phosphite and phosphate retention in soil. N. Z. J. Sci. 1964, 7, 446-451.

39. Ratjen, A.M.; Gerendas, J. A critical assessment of the suitability of phosphite as a source of phosphorus. J. Plant Nutr. Soil Sci. 2009, 172, 821-828.

40. Ouimette, D.G.; Coffey, M.D. Symplastic entry and phloem translocation of phosphonate. Pestic Biochem Physiol. 1990, 38, 18-25. [CrossRef]

41. El-Hamalawi, Z.A.; Menge, J.A.; Adams, C.J. Methods of fosetyl-Al application and phosphonate levels in avocado tissue needed to control stem canker caused by Phytophthora citricola. Plant Dis. 1995, 79, 770-778. Available online: https://europepmc.org/article/agr/ind20478458ex42 (accessed on 16 March 2020). [CrossRef]

42. Schink, B.; Friedrich, M. Phosphite oxidation by sulphate reduction. Nature 2000, 406, 37. [CrossRef] [PubMed]

43. López-Arredondo, D.L.; Herrera-Estrella, L. Engineering phosphorus metabolism in plants to produce a dual fertilization and weed control system. Nat. Biotechnol. 2012, 30, 889-893. [CrossRef] [PubMed]

44. Yu, J.; Broschat, T.K.; Latham, W.G.; Elliott, M.L. Dynamics and Distribution of Trunk injected Phosphite in Coconut Palm. HortScience 2015, 50, 1327-1331. [CrossRef]

45. Malusà, E.; Tosi, L. Phosphorous acid residues in apples after foliar fertilization: Results and of field trials. Food Addit. Contam. 2005, 22, 541-548. [CrossRef]

(C) 2020 by the authors. Licensee MDPI, Basel, Switzerland. This article is an open access article distributed under the terms and conditions of the Creative Commons Attribution (CC BY) license (http://creativecommons.org/licenses/by/4.0/). 